TERM STRUCTURE ESTIMATION. LQQUDITY-INDUCED

HETEROSKEDASTICITY AND THE PRICE OF LIQUIDITY RISK

Emma Berenguer Ricardo Gimeno and Juan na Nave.

Documentos de Trabajo. N. 1308

\title{
baneodespaña
}

\author{
Eurosistema
}


TERM STRUCTURE ESTIMATION, LIQUIDITY-INDUCED HETEROSKEDASTICITY AND THE PRICE OF LIQUIDITY RISK 
TERM STRUCTURE ESTIMATION, LIQUIDITY-INDUCED

\title{
HETEROSKEDASTICITY AND THE PRICE OF LIQUIDITY RISK
}

\author{
Emma Berenguer \\ UNIVERSIDAD PABLO DE OLAVIDE
}

\section{Ricardo Gimeno}

BANCO DE ESPAÑA

Juan M. Nave

UNIVERSIDAD DE CASTILLA-LA MANCHA

\begin{abstract}
Acknowledgements: This paper is the sole responsibility of the authors and the views expressed in it do not necessarily reflect those of the Banco de España. The authors wish to thank participants in internal seminars at Universidad Pablo de Olavide, Universidad de Castilla-La Mancha and the Banco de España for their comments and discussions. We also wish to thank for the valuable comments made by participants of meetings at which previous versions of this paper were presented: the joint Banco de España-Bank of Canada Workshop on "Advances in fixed income modeling" (Madrid, 2011); the European Central Bank Workshop on "Asset pricing models in the aftermath of the financial crisis" (Frankfurt, 2011); the XIX Finance Forum (Granada, 2011), and the EFMA Meeting (Barcelona, 2012). Finally, we wish to thank the Spanish Government (MICINN ECO2009-13616 and MEYC ECO2012-36685), the Generalitat Valenciana (PROMETEOII/2013/01) and Banco Santander (Copernicus UCH-CEU 36/12) for their financial support.
\end{abstract}


The Working Paper Series seeks to disseminate original research in economics and finance. All papers have been anonymously refereed. By publishing these papers, the Banco de España aims to contribute to economic analysis and, in particular, to knowledge of the Spanish economy and its international environment.

The opinions and analyses in the Working Paper Series are the responsibility of the authors and, therefore, do not necessarily coincide with those of the Banco de España or the Eurosystem.

The Banco de España disseminates its main reports and most of its publications via the INTERNET at the following website: http://www.bde.es.

Reproduction for educational and non-commercial purposes is permitted provided that the source is acknowledged.

C BANCO DE ESPAÑA, Madrid, 2013

ISSN: 1579-8666 (on line) 


\section{Abstract}

Since the seminal paper of Vasicek and Fong (1982), the term structures of interest rates have been fitted assuming that yields are cross-sectionally homoskedastic. We show that this assumption does not hold when there are differences in liquidity, even for bonds of the same issuer. Lower turnover implies higher volatility. In addition, a minimum tick size for bond price negotiation will produce higher volatility for bonds approaching their maturity dates. To show these effects, we use data for Spanish sovereign bonds from 1988 to 2010, covering more than 700 bonds and 5000 trading days. We estimate the out-ofsample error for each bond and day. The variance of these errors is found to be negatively correlated with each bond's turnover and duration, while the mean of the errors is found to be directly correlated with the estimated variance. As a result, we propose a modified Svensson (1994) yield curve model to fit the term structure, adding a liquidity term and estimating parameters by weighted least-squared errors to take into account the liquidityinduced heteroskedasticity.

Keywords: heteroskedasticity; liquidity premium; yield curve fitting; Spanish sovereign bonds

JEL Classification: G12, C58, E43. 


\section{Resumen}

Desde la publicación del trabajo de Vasicek y Fong (1982) se ha generalizado el ajuste de la estructura temporal de tipos de interés asumiendo que los rendimientos son homocedásticos. En este trabajo se muestra que dicha hipótesis no se mantiene cuando los activos presentan diferencias en liquidez, incluso cuando se trata de bonos del mismo emisor. Un bajo volumen negociado implica una mayor volatilidad. Además, la existencia de discontinuidades en la negociación del precio de los bonos producirá mayor volatilidad en aquellos que se encuentren más próximos a vencimiento. Para mostrar estos efectos, se ha trabajado con bonos del Estado español desde 1988 hasta 2010, considerando más de 700 títulos y 5.000 días observados. Con estos datos se han estimado los errores fuera de la muestra para cada día y título observados. La varianza de estos errores está negativamente correlacionada con la rotación y la duración de cada título, mientras que la media del error está directamente correlacionada con la varianza estimada. Por todo ello, en este trabajo se propone un modelo modificado de Svensson (1994) para estimar la curva de tipos de interés añadiendo un término por liquidez y estimando los parámetros por mínimos cuadrados ponderados, teniendo en cuenta la heterocedasticidad inducida por liquidez.

Palabras clave: heterocedasticidad, primas de liquidez, ajuste de la curva de tipos de interés, bonos del Estado español.

Códigos JEL: G12, C58, E43. 


\section{Introduction}

Since the paper of Vasicek and Fong (1982), the term structure of interest rates has been estimated assuming that bond yields are homoskedastic, regardless of the methodology used (e.g. Nelson and Siegel, 1987; Svensson, 1994; Bliss, 1997; Jordan and Mansi, 2003). A vast majority of central banks use this assumption in their yield curve estimations (Bank for International Settlements, 2005). Nevertheless, the evidence presented in this paper shows that Vasicek and Fong's (1982) assumption of homoskedastic yield errors no longer holds when the bonds considered have different levels of liquidity.

Since differences in the level of liquidity would cause wider movements for less liquid bonds, on both the upside and the downside, liquidity considerations should imply differences in the variance of yields, even for bonds of the same issuer. The main direct implication of this heteroskedasticity is that parameter estimation of the yield curve would be inefficient.

There is little disagreement in the financial literature that liquidity is the second most important risk factor after credit risk in bond yields. However, it is one of the least understood areas of finance. Amihud and Mendelson (1986) stated that the first consequence of liquidity is the higher or lower return required by investors. These differences are known as liquidity premia and are deviations from the yields of different assets to compensate for differences in liquidity. These liquidity premia have been frequently examined in the literature (e.g. Amihud and Mendelson, 1986; Elton and Green, 1998; Alonso et al., 2004; Diaz et al., 2006).

In the recent financial crisis, where spreads between sovereign bonds (SBs) issued by different countries were used as a measure of credit risk differences, preferences for more liquid bonds may have been distorting the interpretation of these spreads, imposing an upward bias. ${ }^{1}$ Liquidity considerations may have also distorted the differences between nominal bonds and inflation-linked bonds due to inflation compensation, since the higher liquidity of nominal bonds produces a downward bias in supposed market inflation expectations. Lately, the proposal for Eurobonds ${ }^{2}$ has been the subject of intense political debate due to the threat of default on Greek SBs. The argument in favor of these assets points to the liquidity improvement over individual SBs, which could reduce the cost of issuance for all SBs (Delpla and von Weizsäcker, 2010). Therefore, while liquidity spreads have received increasing attention in the literature, the effect of liquidity factors on yield variance has been sidelined.

Alonso et al. (2004) define bond liquidity as the ease of the bond's conversion into money, whereas Díaz et al. (2006) define it as the ease with which a security can be traded within a short period without a significant impact on prices. The main consequence of the lack of liquidity is that, in the case of a trader willing to either buy or sell a given asset, the direction of the trade will have a sizable effect on the price, this movement being upward in the case of a buy order and downward for a sell order. Therefore, price changes will be higher for illiquid assets, implying differences in the associated variance of the bonds due to their different degrees of liquidity.

1 Bond spreads increase during recessions due to phenomena called flight-to-liquidity and flight-to-quality (Goyenko et al., 2011).

2 Defined as "pooled" sovereign debt instruments of the Member States. 
Another issue raised in the literature is the way liquidity is measured. Some studies make inferences about bond liquidity or about the valuation implications of bond liquidity using proxies for liquidity such as security age (Sarig and Warga, 1989), security type (Amihud and Mendelson, 1991; Kamara, 1994), on-the-run/off-the-run status (Warga, 1992), trading volume (Elton and Green, 1998), and term to maturity (Shen and Starr, 1998).

For SBs, Alonso et al. (2004) stated that liquidity should be closely linked to the market makers' inventory risk and order-processing costs, which ultimately depend on the level of risk of the asset (duration) and the frequency with which a transaction will be executed (turnover). On-the-run issues are those more recently auctioned and tend to be more liquid than previously issued bonds (off-the-run) maturing on similar dates (Pasquariello and Vega, 2009). Nevertheless, even among these bonds, there can be differences in liquidity and, therefore, heteroskedasticity among yields.

By contrast, Amihud and Mendelson (1991) proposed a model for short-term interest rates where yields had a variance that was conditional on the time to maturity. Although this approach deals with the duration component of liquidity, it does not consider the trading volume factor. Elton and Green (1998) proposed a term structure model estimated by minimizing the mean root squared error, and then using the errors in a liquidity model where the parameters are determined using heteroskedasticity and autocorrelation-consistent estimation of the variance (HAC estimator). Díaz et al. (2011) considered the heteroskedasticity of the interest rates but used a time series approach rather than a crosssectional liquidity-related approach.

Elton and Green (1998) proposed the trading volume as the main variable producing liquidity differences among bonds of the same issuers. However, since this variable is not always available, some authors have used proxies for it. The most common proxy is the classification of bonds as on-the-run (the most recently auctioned issue), off-the-run (the next most recently auctioned issue), and off-off-the-run (older bonds). That is the case for Alonso et al. (2004) and Diaz et al. (2006), both of whom also include a pre-benchmark category that includes the first days of a new issue, when there is still insufficient trading volume.

Alonso et al. (2004) have verified the existence of liquidity premia in negotiated prices in the Spanish SB market. The methodology used is that of Elton and Green (1998), based on the estimation of the term structure of interest rates. These authors incorporate the effect of liquidity in the estimation, introducing dummy variables for the different categories (e.g. onthe-run/off-the-run) of the bonds. The instantaneous forward rates are defined according to Svensson's (1994) method.

Díaz et al. (2006) analyze the liquidity structure of the Spanish Treasury bond market using trading volume, market share and auction status as proxies for liquidity to determine if the entry of Spain into Stage Three of the Economic and Monetary Union (EMU) has had repercussions on liquidity. The authors also analyze the impact of EMU on the volatility of yields in the Spanish Treasury market, ${ }^{3}$ finding a dramatic decline since the market began pricing in EMU.

The main goal of this paper is to present a model capable of explaining the role played by liquidity in the departure of SB yields from a theoretical liquidity-free interest rate term

3 Díaz et al. (2006) used Nelson and Siegel's (1987) exponential model to fit the daily term structures. They did not incorporate any specific liquidity effects. 
structure. To do so, we propose a heteroskedastic model for the yields, where the variance is a function of the trading volume and the duration, allowing for consistent estimators of the yield curve, in the sense of White (1980). Additionally, following both Elton and Green (1998) and Alonso et al. (2004), we add a liquidity term to the estimation of Svensson's (1994) term structure model. However, we depart from both papers insofar as we use the heteroskedasticity variable estimated for the variance equation for the term structure instead of the trading volume, as in Elton and Green (1998), or the on-the-run/off-the-run status of bonds, as in Alonso et al. (2004). We thus use a model similar to a GARCH-in-mean model.

The rest of the paper is organized as follows. In Section 2 we introduce the problem of efficiency in term structure estimation. Section 3 describes the data. In Section 4 we show that liquidity factors produce heteroskedasticity in SB yields. In Section 5 we modify Svensson's (1994) model to incorporate liquidity when estimating the term structure, in both the mean and variance equations, and estimate it for Spanish SBs. In Section 6 we summarize the main conclusions of the paper. 


\section{Term structure estimation}

The price $\left(P_{i}\right)$ of a coupon-bearing SBs $i$, as is typical of long-term SBs, is equal to

$$
P_{i}=\sum_{j=1}^{m} C_{i j} \cdot e^{-s\left(t_{j} \mid \Phi\right) \cdot t_{j}}+N_{i} \cdot e^{-s\left(t_{m} \mid \Phi\right) \cdot t_{m}}
$$

where $C_{i j}$ are the coupons paid in $t_{j}(j=1, \ldots, m)$, and $N_{i}$ is the nominal paid at the expiration term $(m)$. Each payment is discounted using an interest rate $(s)$ that is a function of time $(t)$ and a set of parameters $(\Phi)$. This function $s(t \mid \Phi)$ is also known as the estimated term structure. Alternatively, we could describe the bond pricing equation using yield to maturity (yield, $y_{i}$ ), defined as the constant interest rate that solves equation (1):

$$
P_{i}=\sum_{j=1}^{n} C_{i j} \cdot e^{-y_{i} \cdot t_{j}}+N \cdot e^{-y_{i} \cdot t_{m}}
$$

For the estimation of the parameter set $\Phi$ in the function $s(t \mid \Phi)$, we have two options:

1. Minimize the error between the observed price $\left(P_{i}\right)$ and that derived from the estimated term structure $\hat{s}(t \mid \Phi),\left(\hat{P}_{i}(\Phi)\right)$,

$$
P_{i}=\hat{P}_{i}(\Phi)+\varepsilon_{i}^{p}
$$

2. Minimize the error between observed yields (i.e., those obtained in equation (2) using the observed price) and those derived from the estimated term structure $\left(\hat{y}_{i}(\Phi)\right)$,

$$
y_{i}=\hat{y}_{i}(\Phi)+\varepsilon_{i}^{y}
$$

Vasicek and Fong (1982) assumed that the error term in equation (4) is homoskedastic $\left(E\left[\left(y_{i}-\hat{y}_{i}(\Phi)\right)^{2}\right]=\sigma^{2}\right)$. Under that assumption, price errors $\left(\varepsilon_{i}^{p}\right)$ would have a variance given by

$$
E\left[\left(P_{i}-\hat{P}_{i}(\Phi)\right)^{2}\right]=\sigma^{2} \cdot\left(\frac{d P_{i}}{d y}\right)^{2}
$$

Expression (5) is easy to interpret because the derivative of the bond price with respect to yield is equal to the bond modified duration $\left(D_{i}\right)$ when price is normalized to one. Therefore, the term structure can be estimated by minimizing either the sum of squared errors in yields,

$$
\widehat{\Phi}=\min _{\Phi} \sum_{i}\left(y_{i}-\hat{y}_{i}(\Phi)\right)^{2}
$$

or the sum of squared weighted (by the inverse of duration) errors in prices,

$$
\widehat{\Phi}=\min _{\Phi} \sum_{i}\left(P_{i}-\hat{P}_{i}(\Phi)\right)^{2} \frac{1}{D_{i}^{2}}
$$

to correct for heteroskedasticity in prices. Both solutions are considered equivalent. For instance, Gurkaynak et al. (2007) used the inverse of the squared duration to weight the errors in price in their estimation of the US Treasury yield curve. In addition, the Bank for International Settlements (2005) reported that, regardless of the type of term structure estimated, five out of eleven central banks estimate term structure by minimizing error in yields (Germany, Norway, Sweden, Switzerland, and the UK), whereas the other six central banks use the weighted errors in prices to estimate term structure (Belgium, Canada, Finland, France, Italy, Spain, and the US). Nevertheless, if Vasicek and Fong's (1982) assumption is rejected and the errors in yield are heteroskedastic, all those estimation methods would be inefficient. 
To check the validity of the assumption of the homoskedasticity of the errors in yields $\left(\varepsilon_{i}^{y}\right)$, we estimate the term structure of interest rates for a long set of data. We need to use bonds from the same issuer with similar levels of credit risk to avoid distortions in the curve that are not related to liquidity: SBs are ideal for this purpose, since the number of securities traded at the same time is high enough to estimate the parameters in a term structure model. Therefore, we use Spanish SBs. These securities are classified, depending on their maturity, as Letras del Tesoro (equivalent to US Treasury bills, short-term zero-coupon bonds, with maturities of up to 18 months), Bonos del Estado (coupon-bearing bonds equivalent to US Treasury notes, with maturities ranging from three to five years, that earn a fixed coupon every year until maturity), and Obligaciones del Estado (similar to Bonos del Estado but issued withmaturities of 10,15 , and 30 years). In all cases, the nominal value is 1000 euros.

Spanish SBs are generally sold via auctions, where privileged dealers (market makers) usually buy a big share of these securities to sell later in the secondary market. Since January 1987, the Treasury uses a unique pricing mechanism (called the Spanish auction) that is a hybrid between uniform and discriminatory auctions (Abbinket al.,2006). The Spanish Treasury performs several auctions every month. Long-term securities (Bonos and Obligaciones) are auctioned by tranche, whereby the issue of a security is kept open over several consecutive auctions (three at least) to improve its liquidity. The securities allocated at such auctions are fungible because they share the same nominal coupons, interest payments, and redemption dates. When the total nominal amount issued reaches a sufficiently high outstanding volume, the corresponding security issuance is closed and a new one opened. In the case of Letras, liquidity is enhanced by a mechanism such that once a 12month bill is close to the six-month term, it is auctioned again as a six-month bill, and again when it is close to the three-month term to redemption when it is auctioned as a three-month bill. Despite their different denominations, hereafter we refer to all Letras, Bonos, and Obligaciones as SBs.

The database is provided by Banco de España's public website and contains all recorded transactions in the secondary market, called the Spanish Public Debt Market. ${ }^{4}$ As explained by Diaz et al. (2006), this database reports the numbers of transactions and the nominal and effective volumes for each issue, as well as the maximum, minimum, and average prices on a daily base. The database provides data from 1988 until 2010, for a total of almost 5000 trading days, 700 issues, and 121,758 observations. From a separate database from the same website, we gather information for each issue (coupons and dates of first issuance and redemption) for the pricing function. In other databases, such as Reuters or Bloomberg, dealers report their bid and ask offers for each bond. Nevertheless, these databases have no information on actual transactions (these must be reported to the Spanish Public Debt Market, and gathered by Banco de España's database) and the offers reported are not binding, so the information has less quality.

As Gurkaynak et al. (2007), from these data we produce daily estimations of the yield curve using Svensson's (1994) model, implementing the genetic algorithm (GA) proposed by Gimeno and Nave (2009), to ensure the stability of the nonlinear optimization. Svensson's (1994)

4 Since 1988 Banco de España has been building a database of closing prices:

http://www.bde.es/webbde/es/secciones/informes/banota/series.html. 
model (NSS) modifies the original work of Nelson and Siegel (1987) by using a second termthe one that Nelson and Siegel (1987) abandoned in their work-and adding two additional parameters $\left(\varphi_{5}\right.$ and $\left.\varphi_{6}\right)$. The equation for the instantaneous forward rate is

$$
f(m)=\varphi_{1}+\varphi_{2} \cdot e^{-\frac{m}{\varphi_{5}}}+\varphi_{3} \cdot \frac{m}{\varphi_{5}} e^{-\frac{m}{\varphi_{5}}}+\varphi_{4} \cdot \frac{m}{\varphi_{6}} e^{-\frac{m}{\varphi_{6}}}
$$

Equation (8) generates a complete family of forward curves that reflects a great variety of term structure shapes (Gurkaynak et al., 2007; Gimeno and Nave, 2009). Integrating equation (8) between $[0, m]$ and dividing by $m$, results in an equation that relates spot interest rates to time to maturity:

$$
s(m)=\phi_{1}+\phi_{2} \frac{1-e^{-m / \phi_{5}}}{\left(m / \phi_{5}\right)}+\phi_{3}\left[\frac{1-e^{-m / \phi_{5}}}{\left(m / \phi_{5}\right)}-e^{-m / \phi_{5}}\right]+\phi_{4}\left[\frac{1-e^{-m / \phi_{6}}}{\left(m / \phi_{6}\right)}-e^{-m / \phi_{6}}\right]
$$

We chose this model based on its appearance in a considerable number of studies, the great number of central banks that use it (Bank for International Settlements, 2005), including Banco de España, and the model's performance for the Spanish government debt market compared to that of other parametric models (Núñez, 1995).

Following Bliss (1997), for each of the 5000 days in the sample, we compute the outof-sample errors in the yields of each bond traded. Since these are out-of-sample errors (each yield is obtained from a term structure estimated with the rest of the bonds traded that day), we have to estimate 121,758 term structures (one for each excluded bond and trading day). Term structure estimations using coupon-bearing bonds are extremely non-linear (Gimeno and Nave, 2009), so for each of the term structures we run 30 GAs to ensure that the estimated parameters do not correspond to a local minimum, raising the total number of term structure estimations above 3.5 million GAs. For these estimations, we use as a target function the minimum squared weighted errors in the prices of equation (7), equivalent to the minimum squared errors in yields but faster to compute. 


\section{$4 \quad$ Liquidity Analysis}

We have estimated the deviations $\left(\varepsilon_{i t}^{y}\right)$ of observed yields from those implied by the estimated term structure of interest rates: the difference between the quoted yield of a bond $(i)$ and its yield implied by the out-of-sample NSS term structure model for a given day (t). If these deviations are affected by liquidity considerations, they should be strongly influenced by two factors, one related to the ease of closing trades and the other to market microstructure. The first factor is the turnover or trading volume $\left(T_{i t}\right)$. When a bond is rarely traded, opposite offers are difficult to match and a willing seller (buyer) would have to accept a lower (higher) price to fulfill the transaction. Warga (1992) and Alonso et al. (2004), among others, classify securities as on-the-run/off-the-run as a proxy for trading volume when turnover data are unavailable. Nevertheless, Elton and Green (1998) signaled that trading volume was a more robust measure of asset liquidity than these other proxies. In our sample, as can be seen in Figure 1, error dispersion is higher for those days when the bond's trading volume is lower. Figure 1 shows the funnel shape characteristic of heteroskedasticity.

Another alternative is the bid-ask spread. However, this measure has two main drawbacks: First, there is no single bid-ask spread for each trading day, since it changes during the day. Although we could compromise with the spread at closing time, the second and more relevant issue is the quality on the bid-ask data. As mentioned in the previous section, information on bid-ask spreads includes non-binding quotes, which can distort the real bid-ask spread. Other problem is the depth of both bid and asks: how many bonds are available to buy or sell at those prices. Sometimes, it may be possible to discern binding from non-binding quotes but, given the scope of our study, we are unable to recover them for each bond and each day.

The tick size is a market microstructure characteristic that produces a second relevant factor from a liquidity point of view. Although all bond prices have the same tick size, changes in price have completely different effects in terms of yield. To illustrate this effect, suppose we have a zero-coupon bond where prices change at a minimum $\Delta$ :

$$
\begin{gathered}
P=e^{-r \cdot m} \\
P+\Delta=e^{-r_{\Delta} \cdot m}
\end{gathered}
$$

Therefore, a change in prices implies a change in yield equal to

$$
r_{\Delta}-r=\frac{1}{m} \cdot \ln \frac{P+\Delta}{P}
$$

Although the logarithm of the price change will be similar for all bonds, changes in yields are inversely related with the bond's term to maturity $(m)$. In the case of coupon-bearing bonds, equation (10) is much more complex, but the effect can be approximated by the time to maturity $\left(D_{i t}\right)$, so those close to maturity will experience, for the same price change, higher return swings than the rest. In this sense, Amihud and Mendelson (1991) found evidence of a liquidity premium that was a decreasing convex function of time to maturity.

Even when prices are allowed to change in a continuum rather than as discrete values, the effect will still be present. Dealers will only trade on a bond if the expected profit compensates them from the trading costs. This profit will be related with the difference between the purchase and sale prices. So, when a bond is close to maturity, dealers will 
accept higher deviations from their bond valuation before it compensates them for the cost of taking a position on that bond.

Figure 2 shows the funnel pattern when comparing errors in yield with bond duration. Although this is a further signal of yield heteroskedasticity, this outcome may not be due to a second factor but, rather, due to the differences in turnover previously mentioned: Bonds close to maturity also tend to be the least traded. We need a multivariate model to consider both factors jointly.

As stated above, liquidity constraints would produce wider movements for less liquid bonds, in both the upside and the downside. Therefore, liquidity considerations should produce differences in the variance of $\varepsilon_{i t}^{y}$ (heteroskedasticity). In this sense, Amihud and Mendelson (1991) proposed a model where yields had a variance conditional on time to maturity. The unobserved variance variable $\left(h_{i t}\right)$ would depend on both turnover (there would be a negative relation between turnover and variance) and duration (there would be a positive relation between the inverse of the duration and the variance). Thus, a heteroskedastic model for the yield errors $\left(\varepsilon_{i t}^{y}\right)$ would be equal to that in equation (11) (model 1):

$$
\begin{array}{ll}
\varepsilon_{i t}^{y}=\beta_{0}+\sqrt{h_{i t}} \cdot u_{i t} & u_{i t} \sim N[0,1] \\
\log h_{i t}=\gamma_{0}+\gamma_{1} \cdot \log T_{i t}+\gamma_{2} \cdot \frac{1}{D_{i t}} &
\end{array}
$$

In the variance equation, we would expect $\gamma_{1}<0$ and $\gamma_{2}>0$ if both the turnover and tick size explain the variance of $\varepsilon_{i t}^{y}$. In Table 1 , model 1 represents the estimations of the parameters of equation (11). As can be seen in Table 1, both the turnover and duration coefficients have the expected signs (negative for turnover and positive for the inverse of the duration). This result confirms that yields are not homoskedastic, a feature we cover in the models of next section.

Although these variables affect primarily the variance of $\varepsilon_{i t}^{y}\left(h_{i t}\right)$, this is far from the only effect expected. Differences in the variance of the yields of different bonds imply different levels of risk for investors. Therefore, we would expect investors to ask for higher returns in the case of bonds susceptible to higher liquidity volatilities. Thus, the level of variance ( $\left.h_{i t}\right)$ would also affect the yield level (the level equation). This second model (model 2) is

$$
\begin{aligned}
& \varepsilon_{i t}^{y}=\beta_{0}+\beta_{1} \cdot \log h_{i t}+\sqrt{h_{i t}} \cdot u_{i t} \\
& \log h_{i t}=\gamma_{0}+\gamma_{1} \cdot \log T_{i t}+\gamma_{2} \cdot \frac{1}{D_{i t}}
\end{aligned}
$$$$
u_{i t} \sim N[0,1]
$$

The variance equation remains invariant with respect to the specification of equation (11), where we expect $\gamma_{1}<0$ and $\gamma_{2}>0$ if both turnover and tick size explain the range of movements in $\varepsilon_{i t}^{y}$. Nevertheless, in the level equation, the heteroskedastic behavior of $\varepsilon_{i t}^{y}$ would be derived from the first term $\left(\sqrt{h_{i t}} \cdot u_{i t}\right)$, while these differences in volatility would be compensated for by a higher liquidity premium $\left(\beta_{1} \cdot \log h_{i t}\right)$. Therefore, we can call the parameter $\beta_{1}$ the price of liquidity risk. We would expect $\beta_{1}>0$, implying that investors demand a premium for the risk they assume. ${ }^{5}$

5 Although it is reasonable to suppose that the price of risk change in time (increasing with the crisis and decreasing in normal times) for simplicity we have suppose in this section that the price of risk is constant. In next section, we present a model where the price of risk is estimated in a daily base. 
The second model of Table 1 presents the parameter estimations of model (12). As can be seen in Table 1, the parameters estimated in the variance equation are similar to those obtained in model 1 and both the turnover and duration coefficients have the expected signs (negative for turnover and positive for the duration). The main difference is in the case of the level equation, where we also find the expected positive (and significant) price of risk. 


\section{A proposal for a modified Svensson model}

In the previous section we show that Vasicek and Fong's (1982) assumption of homoskedastic yield errors no longer holds when the bonds have different levels of liquidity. Under these circumstances, the usual optimization functions (equations (6) and (7)) exacerbate the observed heteroskedasticity instead of correcting it. As a result, term structure estimations (such as those obtained in Section 3) are not efficient, tending to use the wrong weighting, since they rely too much on duration and avoid others sources of uncertainty, such as turnover.

In fact, the variance for the price error would be better described by equation (13), where the constant yield variance $\left(\sigma^{2}\right)$ has been replaced by the heteroskedastic version $\left(h_{i}\right)$ proposed in equations (11) and (12):

$$
\begin{aligned}
& E\left[\left(P_{i}-\hat{P}_{i}(\Phi)\right)^{2}\right]=h_{i} \cdot\left(\frac{d P_{i}}{d y}\right)^{2} \\
& \log h_{i t}=\gamma_{0}+\gamma_{1} \cdot \log T_{i t}+\gamma_{2} \cdot \frac{1}{D_{i t}}
\end{aligned}
$$

In this section we propose several ways to include the liquidity factor in the term structure estimation.

\subsection{Liquidity weighting}

A straightforward way to estimate the term structure is to jointly estimate the parameters of both the term structure (equation (9)) and the variance equation (equation (14)), using, as the function we want to minimize, the squared errors in prices weighted by the variance of yields times the squared bond duration:

$$
(\widehat{\Phi}, \hat{\gamma})=\min _{\Phi, \gamma} \sum_{i}\left(P_{i}-\hat{P}_{i}(\Phi)\right)^{2} \frac{1}{D_{i}^{2} h_{i}(\gamma)}
$$

Although we apply the optimization criteria of equation (15) to estimate Svensson's model, this modification can also be used for any other term structure estimation methodology, whether parametric-for example, Nelson and Siegel's (1987) model-or nonparametric - for example, Vasicek and Fong's (1982) splines.

\subsection{Liquidity premium}

The previous model specification does not take into account the presence of an eventual liquidity premium; it just takes into account the variability in prices derived from these liquidity considerations. To include this premium in the model, we should vary the pricing equation (equation (1)) to add an additional term:

$$
\hat{P}_{i}=\sum_{j=1}^{m} C_{i j} \cdot e^{-\left(s\left(t_{j}, \varphi\right) \cdot t_{j}+\alpha \cdot h_{i}\right)}+N_{i} \cdot e^{-\left(s\left(t_{m}, \varphi\right) \cdot t_{m}+\alpha \cdot h_{i}\right)}
$$

This modification is equivalent to multiplying the estimated price by $e^{-\alpha \cdot h}$ or to adding a premium $(\alpha h / t)$ to the bond yield. The variance equation (equation (15)) would remain valid and the function we want to optimize now is

$$
(\widehat{\Phi}, \hat{\gamma}, \hat{\alpha})=\min _{\Phi, \gamma, \alpha} \sum_{i}\left(P_{i}-\hat{P}_{i}(\Phi, \gamma, \alpha)\right)^{2} \frac{1}{D_{i}{ }^{2} h_{i}(\gamma)}
$$


The introduction of the liquidity model proposed in equation (16) is similar to that of Elton and Green (1998), where the logarithm of the trading volume was added for the pricing equation, although the authors did not consider the liquidity-induced heteroskedasticity to modify their weighting.

\subsection{Term structure estimation}

Tables 2a-2c present term structure estimations for three different days: April 20, 2010 (on the way to the first euro area sovereign debt crisis); May 11, 2010 (right in the middle of the first Greek sovereign debt crisis); and July 7, 2010 (in the middle of the market easing after the publication of the first European banks' stress tests). For each day, we compute four different estimations:

1. A traditional Svensson model (equation (9)), minimizing equation (7), that is, traditional weighting error prices using the squared modified bond duration.

2. A Svensson model (equation (9)), but minimizing equation (17). To obtain the estimated variances $\left(\hat{h}_{i t}\right)$, we need to compute the weights, which we carry out in a two-step process. First, we compute the squared differences between the observed and estimated yields $(y)$ from the previous model and then estimate a regression similar to the one we would use in a White heteroskedasticity test,

$$
\log \left(\mathrm{y}_{\mathrm{it}}-\hat{\mathrm{y}}_{\mathrm{it}}\right)^{2}=\gamma_{0}+\gamma_{1} \cdot \log \mathrm{T}_{\mathrm{it}}+\gamma_{2} \cdot \frac{1}{\mathrm{D}_{\mathrm{it}}}
$$

Finally, we use this modeled variance to estimate the term structure, minimizing equation(17).

3. Instead of two steps, a joint estimation of the mean (Svensson's equation (9)) and variance (equation (14)) estimation (minimizing equation (17)). In this case, we do not need to rely on obtaining the traditional duration-weighted estimators in the first step of the variance equation.

4. A model with a liquidity premium (equation (16))-where we include compensation for liquidity risk $(\alpha)$ in the price equation as well as a variance equation (equation (14)) - that we jointly estimate using the optimization approach of equation (17).

As can be seen in Figures 3-5, yield curves can vary greatly, depending on the specification. Furthermore, the liquidity premium can change from day to day: It was higher in the middle of the Greek debt crisis (May 11, 2010) than before or after. 
In this paper we show how differences in the liquidity of bonds with the same credit risk produce yields that differ from those expected in a theoretical liquidity-free term structure of interest rates. We observe that differences in bonds' liquidity affect their volatility. Bond yields have an expected value equal to that associated with the term structure of interest rates and a variance that depends on liquidity factors that we identify with the bond's trading volume and duration. We find that the variance is negatively related to turnover and positively related to duration. This finding suggests that liquidity differences between bonds of the same issuer can produce heteroskedasticity.

The main direct implication of this heteroskedasticity is for the estimation of the yield curve. Vasicek and Fong (1982) estimated the term structure of interest rates by assuming that bond returns are homoskedastic and they proposed an error correction that consisted in weighting the squared price errors by the inverse of duration. Our findings imply that this hypothesis does not hold for bonds with differences in liquidity levels, even when they are of the same issuer. Therefore, estimations of cross-sectional models of term structure should be corrected to take into account the liquidity factor.

Finally, as a solution to the rejection of Vasicek and Fong's (1982) hypothesis, we propose the use of a new optimization program that takes liquidity factors into account. Additionally, we propose a Svensson model modified by adding a liquidity risk premium, drawing on the findings of this paper. 
TABLE 1: Heteroskedastic models for out-of-sample yield errors.

\begin{tabular}{|c|c|c|c|c|}
\hline \multirow{2}{*}{ Level Equation } & \multicolumn{2}{|c|}{ Model 1} & \multicolumn{2}{|c|}{ Model 2} \\
\hline & & & & \\
\hline Intercept & -0.989 & & -0.240 & \\
\hline $\log \left(h_{i t}\right)$ & & & 0.184 & $* * *$ \\
\hline Variance Equation & & & & \\
\hline Intercept & 3.373 & & 3.290 & \\
\hline $\log \left(\right.$ Turnover $\left._{i t}\right)$ & -0.133 & $* * *$ & -0.129 & $* * *$ \\
\hline $1 /$ Duration $_{i t}$ & 0.139 & $* * *$ & 0.142 & $* * *$ \\
\hline \# of observations & 121,758 & & 121,758 & \\
\hline \# of days & 4,996 & & 4,996 & \\
\hline \# of bonds & 662 & & 662 & \\
\hline
\end{tabular}

In both models 1 and 2, the dependent variable for each $i$ th bond and day is the difference between the quoted yield and that derived from an NSS term structure model estimated each day for all Spanish SBs traded that day, but excluding the $i$ th bond. Turnover is measured in thousands of euros and duration is measured in years. Model 1 corresponds to the model specified in equation (11), whereas model 2 corresponds to the model specified in equation (12). Individual likelihood ratio tests were computed for each parameter (outside the intercepts) under the null hypothesis of a non-significant variable. The superscripts $* * * * *$, and $*$ denote rejection of the null at the $1 \%, 5 \%$, and $10 \%$ levels, respectively.

TABLE 2a: Term structure of Spanish government bonds, April 20, 2010.

\begin{tabular}{|c|c|c|c|c|}
\hline & $\begin{array}{c}\text { Duration } \\
\text { Weighted }\end{array}$ & $\begin{array}{l}\text { Liquidity } \\
\text { Weighted }\end{array}$ & $\begin{array}{l}\text { Mean-Variance } \\
\text { Joint Estimation }\end{array}$ & $\begin{array}{c}\text { Liquidity } \\
\text { Premium Model }\end{array}$ \\
\hline \multicolumn{5}{|c|}{ Svensson model } \\
\hline$\varphi_{1}$ & 0.023 & 0.023 & 0.022 & 0.022 \\
\hline$\varphi_{2}$ & -0.020 & -0.020 & -0.020 & -0.020 \\
\hline$\varphi_{3}$ & 0.062 & 0.060 & 0.067 & 0.067 \\
\hline$\varphi_{4}$ & 0.069 & 0.068 & 0.081 & 0.081 \\
\hline$\varphi_{5}$ & 6.983 & 6.965 & 6.593 & 6.776 \\
\hline$\varphi_{6}$ & 25.991 & 25.260 & 38.915 & 38.915 \\
\hline \multicolumn{5}{|c|}{ Variance equation } \\
\hline$\gamma_{0}$ & - & -13.392 & 12.971 & 12.971 \\
\hline$\gamma_{1}$ & - & -0.191 & -0.235 & -0.235 \\
\hline$\gamma_{2}$ & - & 0.667 & 1.458 & 1.458 \\
\hline
\end{tabular}

Price of risk

$\alpha$

$-$

0.000121

The duration-weighted model corresponds to the estimation of model (9) using optimization program (7). The liquidity-weighted model corresponds to the estimation of model (9) using optimization program(15), where liquidity variance was previously estimated from equation (14). The mean-variance joint estimation model is equal to the liquidity-weighted model, but the variance and mean equations (14) and (9), respectively, are estimated simultaneously. The liquidity premium model includes mean equation (16), variance equation (14), and optimization program (17). 
TABLE 2b: Term structure of Spanish government bonds, May 11, 2010.

\begin{tabular}{|c|c|c|c|c|}
\hline & $\begin{array}{c}\text { Duration } \\
\text { Weighted }\end{array}$ & $\begin{array}{l}\text { Liquidity } \\
\text { Weighted }\end{array}$ & $\begin{array}{l}\text { Mean-Variance } \\
\text { Joint Estimation }\end{array}$ & $\begin{array}{c}\text { Liquidity } \\
\text { Premium Model }\end{array}$ \\
\hline \multicolumn{5}{|c|}{ Svensson model } \\
\hline$\varphi_{1}$ & 0.050 & 0.053 & 0.058 & 0.058 \\
\hline$\varphi_{2}$ & -0.045 & -0.053 & -0.058 & -0.058 \\
\hline$\varphi 3$ & 0.000 & 0.002 & 0.036 & 0.044 \\
\hline$\varphi_{4}$ & 0.107 & 0.075 & 0.039 & 0.029 \\
\hline$\varphi_{5}$ & 2.668 & 9.092 & 8.881 & 7.414 \\
\hline$\varphi_{6}$ & 138.866 & 6.987 & 2.245 & 0.806 \\
\hline \multicolumn{5}{|c|}{ Variance equation } \\
\hline$\gamma_{0}$ & - & -14.743 & -24.633 & -0.003 \\
\hline$\gamma_{1}$ & - & -0.010 & -0.057 & -0.149 \\
\hline$\gamma_{2}$ & - & 0.918 & 0.916 & 1.697 \\
\hline
\end{tabular}

Price of risk

$$
\alpha
$$

The duration-weighted model corresponds to the estimation of model (9) using optimization program (7). The liquidity-weighted model corresponds to the estimation of model (9) using optimization program (15), where liquidity variance was previously estimated from equation (14). The mean-variance joint estimation model is equal to the liquidity-weighted model, but the variance and mean equations (14) and (9), respectively, are estimated simultaneously. The liquidity premium model includes mean equation (16), variance equation (14), and optimization program (17).

TABLE 2c: Term structure of Spanish government bonds, July 7, 2010.

\begin{tabular}{|c|c|c|c|c|}
\hline & $\begin{array}{l}\text { Duration } \\
\text { Weighted }\end{array}$ & $\begin{array}{l}\text { Liquidity } \\
\text { Weighted }\end{array}$ & $\begin{array}{l}\text { Mean-Variance } \\
\text { Joint Estimation }\end{array}$ & $\begin{array}{c}\text { Liquidity } \\
\text { Premium Model }\end{array}$ \\
\hline \multicolumn{5}{|c|}{ Svensson model } \\
\hline$\varphi_{1}$ & 0.035 & 0.036 & 0.030 & 0.027 \\
\hline$\varphi_{2}$ & -0.032 & -0.036 & -0.030 & -0.027 \\
\hline$\varphi_{3}$ & 0.000 & 0.009 & 0.001 & 0.000 \\
\hline$\varphi_{4}$ & 0.082 & 0.078 & 0.097 & 0.104 \\
\hline$\varphi_{5}$ & 0.612 & 0.935 & 0.394 & 0.300 \\
\hline$\varphi_{6}$ & 20.371 & 16.864 & 16.221 & 15.140 \\
\hline \multicolumn{5}{|c|}{ Variance equation } \\
\hline$\gamma_{0}$ & - & -12.637 & -0.111 & 0.159 \\
\hline$\gamma_{1}$ & - & 1.106 & -0.119 & 0.830 \\
\hline$\gamma_{2}$ & - & 22.858 & -0.128 & 0.843 \\
\hline
\end{tabular}

Price of risk

$\alpha$

-

0.000000

The duration-weighted model corresponds to the estimation of model (9) using optimization program (7). The liquidity-weighted model corresponds to the estimation of model (9) using optimization program (15), where liquidity variance was previously estimated from equation (14). The mean-variance joint estimation model is equal to the liquidity-weighted model, but variance and mean equations (14) and (9), respectively, are estimated simultaneously. The liquidity premium model includes mean equation (16), variance equation (14), and optimization program (17). 
FIGURE 1.Errors in yields of Spanish SBs versus turnover Out-of-sample errors were estimated using Svensson's (1994) model, 1988 to 2010.

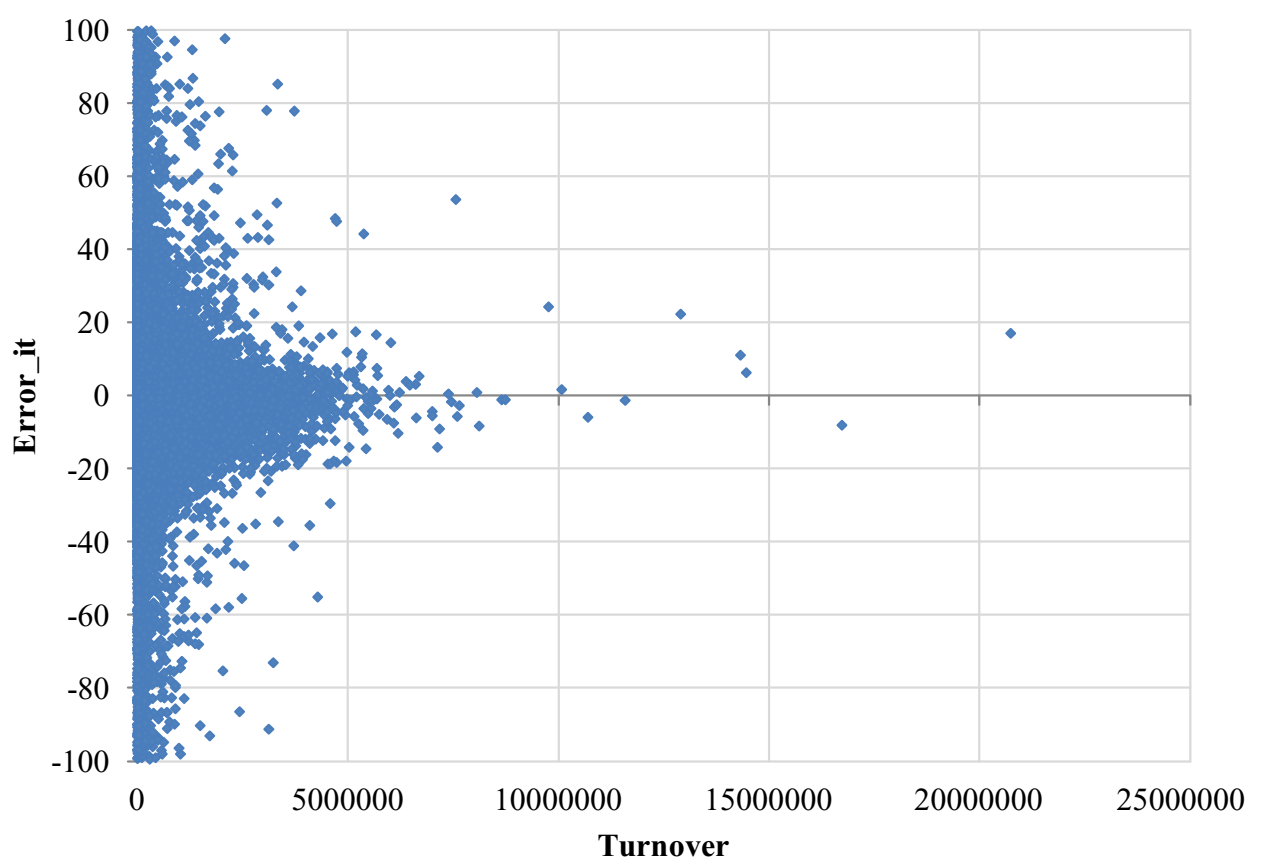

FIGURE 2.Errors in yields of Spanish SBs versus duration Out-of-sample errors were estimated using Svensson's (1994) model, 1988 to 2010.

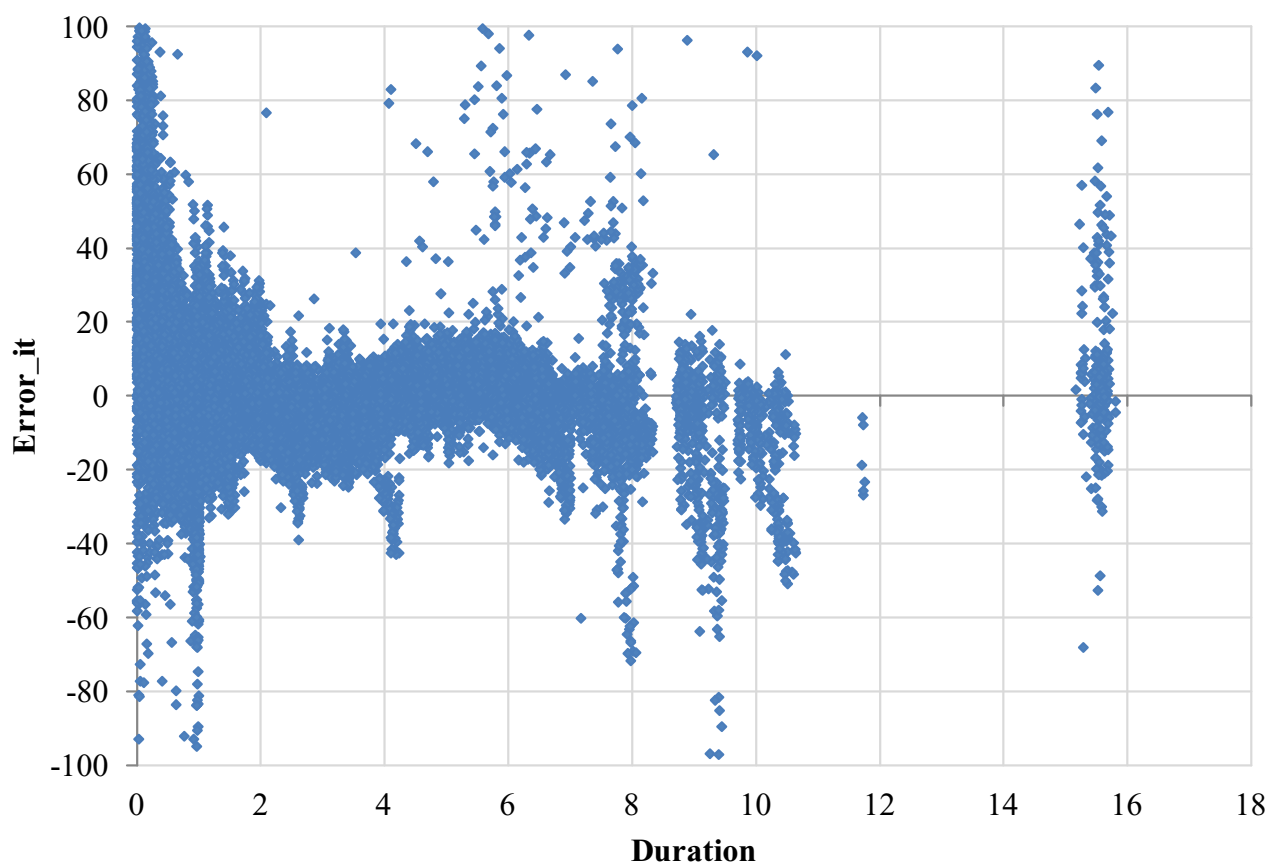


Figure 3. Term structure of Spanish government bonds, April 20, 2010
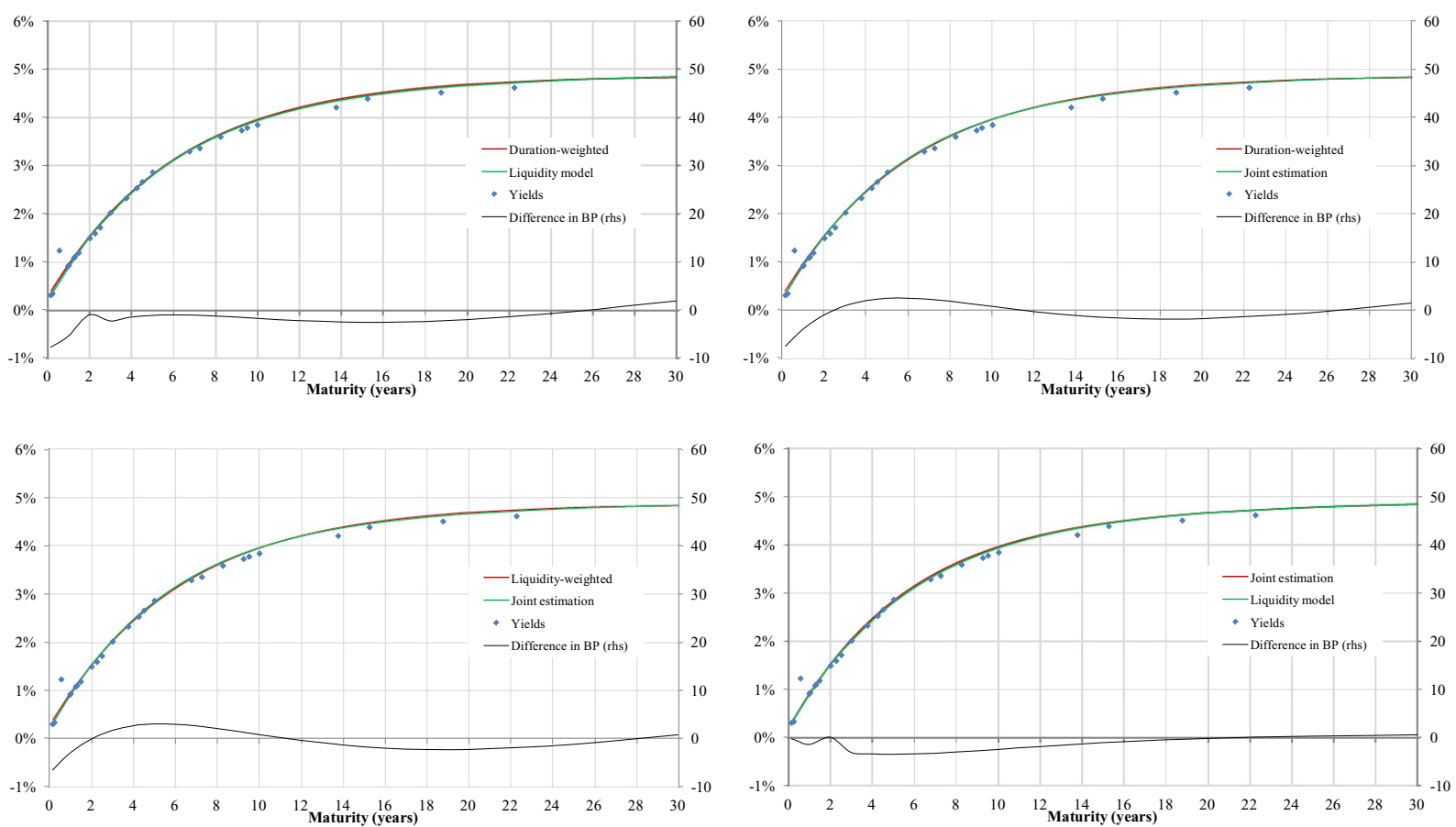

This figure shows the par yield curves, where the dots are yields versus time to maturity. The chart in the upper left represents the traditional estimation curve based on weighting observations by their squared duration (red) and the modified Svensson model, where the curve is estimated using liquidity weighting and adding a liquidity premium (green), although the plotted curve does not include this premium, which would be different for each bond. Differences between both curves are represented in the right-hand axis in basis points (black). The chart in the upper right compares the traditional squared duration weighting (red) and liquidity weighting without liquidity premia (green). The chart in the lower left compares the liquidity weighting estimation in a two-step approach (red) and a joint estimation of level and variance equations (green). The chart in the lower right compares liquidity weighting (red) with the modified Svensson model, where the curve is estimated using liquidity weighting and adding a liquidity premium (green), although the plotted curve does not include this premium, which would be different for each bond. 
Figure 4. Term structure of Spanish government bonds, May 11, 2010
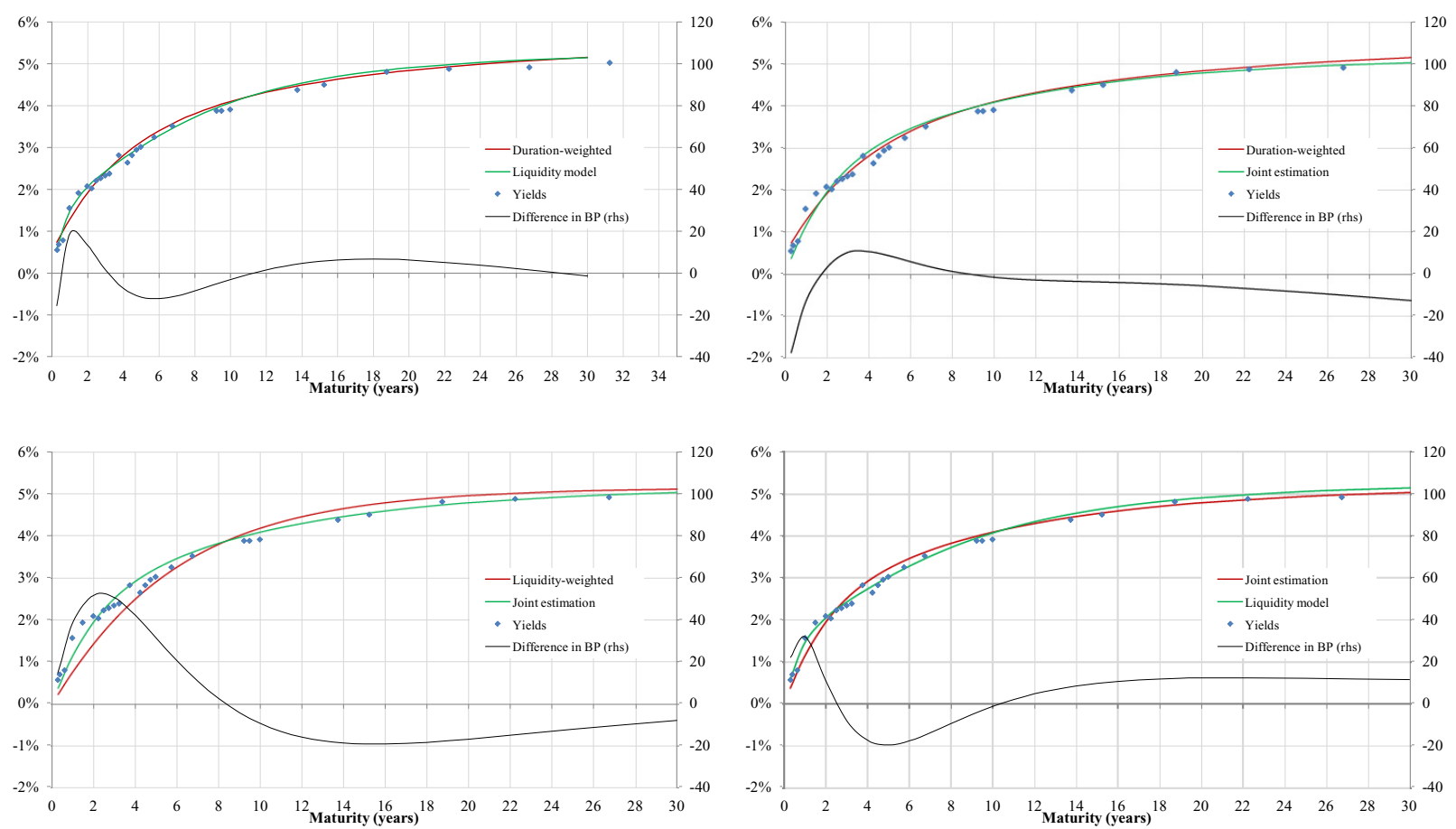

This figure shows the par yield curves, where the dots are yields versus time to maturity. The chart in the upper left shows the traditional estimation curve based on weighting observations by their squared duration (red) and the modified Svensson model, where the curve is estimated using liquidity weighting and adding a liquidity premium (green), although the plotted curve does not include this premium, which would be different for each bond. The differences between both curves are shown in the right-hand axis in basis points (black). The chart in the upper right compares the traditional squared duration weighting (red) and liquidity weighting without liquidity premia (green). The chart in the lower left compares the liquidity weighting estimation in a two-step approach (red) and a joint estimation of level and variance equations (green). The chart in the lower right compares liquidity weighting (red) with the modified Svensson model, where the curve is estimated using liquidity weighting and adding a liquidity premium (green), although the plotted curve does not include this premium, which would be different for each bond. 
Figure 5. Term structure of Spanish government bonds, July 7, 2010
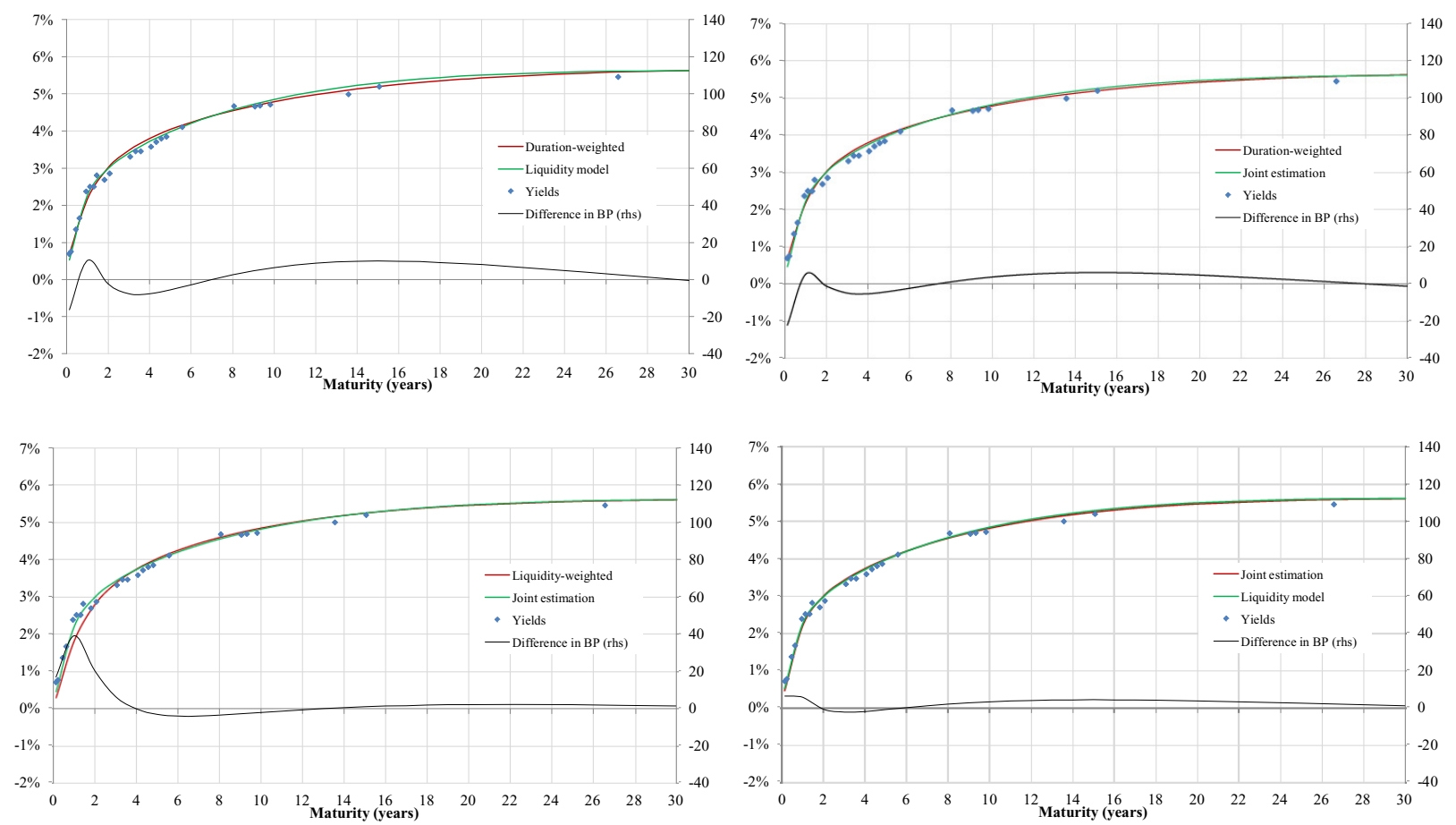

This figures show the par yield curves, where the dots are yields versus time to maturity. The chart in the upper left shows the traditional estimation curve based on weighting observations by their squared duration (red) and the modified Svensson model, where the curve is estimated using liquidity weighting and adding a liquidity premium (green), although the plotted curve does not include this premium, which would be different for each bond. The differences between both curves are shown in the right-hand axis in basis points (black). The chart in the upper right compares the traditional squared duration weighting (red) and liquidity weighting without liquidity premia (green). The chart in the lower left compares the liquidity weighting estimation in a two-step approach (red) and a joint estimation of level and variance equations (green). The chart in the lower right compares liquidity weighting (red) with the modified Svensson model, where the curve is estimated using liquidity weighting and adding a liquidity premium (green), although the plotted curve does not include this premium, which would be different for each bond. 


\section{REFERENCES}

ABBINK, K., BRANDTS, J. AND PEZANIS-CHRISTOU, P., 2006. "Auctions for Governments Securities: A Laboratory Comparison of Uniform, Discriminatory and Spanish Designs." Journal of Economic Behavior and Organization, vol. 61, pp. 284-303.

ALONSO, F., BLANCO, R., RÍO, A.D. AND SANCHÍS, A., 2004."Estimating Liquidity Premia in the Spanish Government Securities Market." European Journal of Finance, vol. 10, no. 6, pp. 453-474.

AMIHUD, Y. AND MENDELSON, H., 1986. "Asset Pricing and the Bid-Ask Spread." Journal of Financial Economics, vol. 17, no. 2, pp. 223-249.

AMIHUD, Y. AND MENDELSON, H., 1991. "Liquidity, Maturity, and the Yields on US Treasury Securities." Journal of Finance, vol. 46, no. 4, pp. 1411-1425.

BANK FOR INTERNATIONAL SEITLEMENTS, 2005.Zero Coupon Yield Curves: Technical Documentation. BIS Papers no. 25.

BLISS, R.R., 1997. "Testing Term Structure Estimation Methods." Advances in Futures and Options Research, vol. 9, pp. 197-232.

DELPLA J. AND VON WEIZSÄCKER, J., 2010, "The Blue Bond proposal." Bruegel Policy Brief no. 2010/03.

DÍAZ, A, JAREÑO, F. AND NAVARRO, E., 2011. "Term Structure of Volatilities and Yield Curve Estimation Methodology."Quantitative Finance, vol. 11, no. 4, 573-586.

DÍAZ, A, MERRICK, J.J. AND NAVARRO, E., 2006."Spanish Treasury Bond Market Liquidity and Volatility Pre- and PostEuropean Monetary Union." Journal of Banking and Finance.vol. 30, 1309-1332.

ELTON, E.J. AND GREEN, T.C., 1998. "Tax and Liquidity Effects in Pricing Government Bonds." Journal of Finance, vol. 53, no. 5, pp. 1533-1562.

GIMENO, R. AND NAVE, J.M., 2009. "A Genetic Algorithm Estimation of the Term Structure of Interest Rates." Computational Statistics \& Data Analysis, vol. 53, no. 6, pp. 2236-2250.

GOYENKO, R., SUBRAHMANYAM, A. AND UKHOV, A., 2011. "The Term Structure of Bond Market Liquidity and Its Implications for Expected Bond Returns.” Journal of Financial and Quantitative Analysis, vol. 46, pp. 111-139.

GURKAYNAK, R.S., SACK, B. AND WRIGHT, J.H., 2007, "The US Treasury Yield Curve: 1961 to the Present." Journal of Monetary Economics, vol. 54, no. 8, pp. 2291-2309.

JORDAN, J. AND S. MANSI, 2003."Term Structure Estimation from On-the-Run Treasuries."Journal of Banking and Finance, vol. 27, pp. 1487-1509.

KAMARA, A., 1994. "Liquidity, Taxes, and Short-Term Treasury Yields." Journal of Financial and Quantitative Analysis, vol. 29, no. 3, pp. 403-417.

NELSON, C.R. AND SIEGEL, A.F., 1987. "Parsimonious Modeling of Yield Curves."Journal of Business, vol. 60, no. 4, pp. 473-489.

NúÑEZ, S., 1995. "Estimación de la Estructura Temporal de Tipos de Interés en España: Elección entre Métodos Alternativos." Work paper n 9522, Banco de España.

PASQUARIELLO, P. AND VEGA, C., 2009. "The on-the-run liquidity phenomenon."Journal of Financial Economics, vol. 92, no. 1, pp. 1-24.

SARIG, O. AND A. WARGA, 1989."Bond Price Data and Bond Market Liquidity."Journal of Financial and Quantitative Analysis, vol. 24, pp. 367-378.

SHEN, P. AND STARR, R.M., 1998. "Liquidity of the Treasury Bill Market and the Term Structure of Interest Rates." Journal of Economics and Business, vol. 50, no. 5, pp. 401-417.

SVENSSON, L.E.O., 1994. "Estimating and Interpreting Forward Interest Rates: Sweden 1992-1994." International Monetary Fund Working Paper No.WP/94/114.

VASICEK, O.A. AND FONG, H.G., 1982. "Term Structure Modeling using Exponential Splines." Journal of Finance, vol. 37, no. 2, pp. 339-348.

WARGA, A., 1992. "Bond Returns, Liquidity, and Missing Data." Journal of Financial and Quantitative Analysis, vol. 27, no. 4, pp. 605-617.

WHITE, H., 1980. "A Heteroskedasticity-Consistent Covariance Matrix Estimator and a Direct Test for Heteroskedasticity."Econometrica, vol. 48, pp. 817-838. 
BANCO DE ESPAÑA PUBLICATIONS

\author{
WORKING PAPERS
}

1201 CARLOS PÉREZ MONTES: Regulatory bias in the price structure of local telephone services.

1202 MAXIMO CAMACHO, GABRIEL PEREZ-QUIROS and PILAR PONCELA: Extracting non-linear signals from several economic indicators.

1203 MARCOS DAL BIANCO, MAXIMO CAMACHO and GABRIEL PEREZ-QUIROS: Short-run forecasting of the euro-dollar exchange rate with economic fundamentals.

1204 ROCIO ALVAREZ, MAXIMO CAMACHO and GABRIEL PEREZ-QUIROS: Finite sample performance of small versus large scale dynamic factor models.

1205 MAXIMO CAMACHO, GABRIEL PEREZ-QUIROS and PILAR PONCELA: Markov-switching dynamic factor models in real time.

1206 IGNACIO HERNANDO and ERNESTO VILLANUEVA: The recent slowdown of bank lending in Spain: are supply-side factors relevant?

1207 JAMES COSTAIN and BEATRIZ DE BLAS: Smoothing shocks and balancing budgets in a currency union.

1208 AITOR LACUESTA, SERGIO PUENTE and ERNESTO VILLANUEVA: The schooling response to a sustained Increase in low-skill wages: evidence from Spain 1989-2009.

1209 GABOR PULA and DANIEL SANTABÁRBARA: Is China climbing up the quality ladder?

1210 ROBERTO BLANCO and RICARDO GIMENO: Determinants of default ratios in the segment of loans to households in Spain.

1211 ENRIQUE ALBEROLA, AITOR ERCE and JOSÉ MARÍA SERENA: International reserves and gross capital flows. Dynamics during financial stress.

1212 GIANCARLO CORSETTI, LUCA DEDOLA and FRANCESCA VIANI: The international risk-sharing puzzle is at businesscycle and lower frequency.

1213 FRANCISCO ALVAREZ-CUADRADO, JOSE MARIA CASADO, JOSE MARIA LABEAGA and DHANOOS SUTTHIPHISAL: Envy and habits: panel data estimates of interdependent preferences.

1214 JOSE MARIA CASADO: Consumption partial insurance of Spanish households.

1215 J. ANDRÉS, J. E. BOSCÁ and J. FERRI: Household leverage and fiscal multipliers.

1217 ARTURO MACÍAS and MARIANO MATILLA-GARCÍA: Net energy analysis in a Ramsey-Hotelling growth model.

1218 ALFREDO MARTÍN-OLIVER, SONIA RUANO and VICENTE SALAS-FUMÁS: Effects of equity capital on the interest rate and the demand for credit. Empirical evidence from Spanish banks.

1219 PALOMA LÓPEZ-GARCÍA, JOSÉ MANUEL MONTERO and ENRIQUE MORAL-BENITO: Business cycles and investment in intangibles: evidence from Spanish firms.

1220 ENRIQUE ALBEROLA, LUIS MOLINA and PEDRO DEL RÍO: Boom-bust cycles, imbalances and discipline in Europe.

1221 CARLOS GONZÁLEZ-AGUADO and ENRIQUE MORAL-BENITO: Determinants of corporate default: a BMA approach.

1222 GALO NUÑO and CARLOS THOMAS: Bank leverage cycles.

1223 YUNUS AKSOY and HENRIQUE S. BASSO: Liquidity, term spreads and monetary policy.

1224 FRANCISCO DE CASTRO and DANIEL GARROTE: The effects of fiscal shocks on the exchange rate in the EMU and differences with the US.

1225 STÉPHANE BONHOMME and LAURA HOSPIDO: The cycle of earnings inequality: evidence from Spanish social security data.

1226 CARMEN BROTO: The effectiveness of forex interventions in four Latin American countries.

1227 LORENZO RICCI and DAVID VEREDAS: TailCoR.

1228 YVES DOMINICY, SIEGFRIED HÖRMANN, HIROAKI OGATA and DAVID VEREDAS: Marginal quantiles for stationary processes.

1229 MATTEO BARIGOZZI, ROXANA HALBLEIB and DAVID VEREDAS: Which model to match?

1230 MATTEO LUCIANI and DAVID VEREDAS: A model for vast panels of volatilities.

1231 AITOR ERCE: Does the IMF's official support affect sovereign bond maturities?

1232 JAVIER MENCÍA and ENRIQUE SENTANA: Valuation of VIX derivatives.

1233 ROSSANA MEROLA and JAVIER J. PÉREZ: Fiscal forecast errors: governments vs independent agencies? 
1234 MIGUEL GARCÍA-POSADA and JUAN S. MORA-SANGUINETTI: Why do Spanish firms rarely use the bankruptcy system? The role of the mortgage institution.

1235 MAXIMO CAMACHO, YULIYA LOVCHA and GABRIEL PEREZ-QUIROS: Can we use seasonally adjusted indicators in dynamic factor models?

1236 JENS HAGENDORFF, MARÍA J. NIETO and LARRY D. WALL: The safety and soundness effects of bank M\&As in the EU: Does prudential regulation have any impact?

1237 SOFÍA GALÁN and SERGIO PUENTE: Minimum wages: do they really hurt young people?

1238 CRISTIANO CANTORE, FILIPPO FERRONI and MIGUEL A. LEÓN-LEDESMA: The dynamics of hours worked and technology.

1239 ALFREDO MARTÍN-OLIVER, SONIA RUANO and VICENTE SALAS-FUMÁS: Why did high productivity growth of banks precede the financial crisis?

1240 MARIA DOLORES GADEA RIVAS and GABRIEL PEREZ-QUIROS: The failure to predict the Great Recession. The failure of academic economics? A view focusing on the role of credit.

1241 MATTEO CICCARELLI, EVA ORTEGA and MARIA TERESA VALDERRAMA: Heterogeneity and cross-country spillovers in macroeconomic-financial linkages.

1242 GIANCARLO CORSETTI, LUCA DEDOLA and FRANCESCA VIANI: Traded and nontraded goods prices, and international risk sharing: an empirical investigation.

1243 ENRIQUE MORAL-BENITO: Growth empirics in panel data under model uncertainty and weak exogeneity.

1301 JAMES COSTAIN and ANTON NAKOV: Logit price dynamics.

1302 MIGUEL GARCÍA-POSADA: Insolvency institutions and efficiency: the Spanish case.

1303 MIGUEL GARCÍA-POSADA and JUAN S. MORA-SANGUINETTI: Firm size and judicial efficacy: evidence for the new civil procedures in Spain.

1304 MAXIMO CAMACHO and GABRIEL PEREZ-QUIROS: Commodity prices and the business cycle in Latin America: living and dying by commodities?

1305 CARLOS PÉREZ MONTES: Estimation of regulatory credit risk models.

1306 FERNANDO LÓPEZ VICENTE: The effect of foreclosure regulation: evidence for the US mortgage market at state level.

1307 ENRIQUE MORAL-BENITO and LUIS SERVEN: Testing weak exogeneity in cointegrated panels.

1308 EMMA BERENGUER, RICARDO GIMENO and JUAN M. NAVE: Term structure estimation, liquidity-induced heteroskedasticity and the price of liquidity risk.

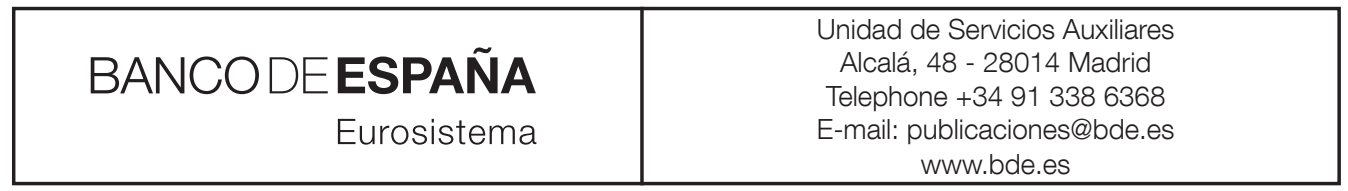

